\title{
Long-Term Vegetation Productivity and Trend Under Two Stocking Levels on Chihuahuan Desert Rangeland
}

\author{
Godfrey Khumalo, ${ }^{1}$ Jerry Holechek, ${ }^{2}$ Milt Thomas, ${ }^{3}$ and \\ Francisco Molinar ${ }^{4}$
}

Authors are ${ }^{1} \mathrm{PhD}$ Student, ${ }^{2}$ Professor, and ${ }^{3}$ Associate Professor, Department of Animal and Range Sciences, New Mexico State University, Las Cruces, NM 88003; and ${ }^{4}$ Range Conservationist, USDA-NRCS, Guymon, OK 73942.

\begin{abstract}
Vegetation changes were evaluated over an 11-year period (1995-2005) on 2 light- and 2 conservative-stocked Chihuahuan Desert pastures in south central New Mexico. Grazing treatments were applied to the pastures over a 5-year period from 1997 through 2001. Pastures were not grazed in the 1995-1996 and 2002-2005 periods due to drought. During the 1997-2001 grazing period, grazing use of primary forage species averaged $29 \%$ and $40 \%$ on light- and conservative-stocked rangelands, respectively. Grazing intensity was consistently higher on conservative-stocked than light-stocked pastures. During our study heavy grazing occurred only in 1 year on pastures with conservative stocking. There were no differences in species or species categories (grasses, forbs, shrubs) of autumn standing crop and basal cover between light-and conservative-stocked pastures. Standing crop of total vegetation and perennial grasses showed large fluctuations among the years due to variable rainfall. Under both treatments, total herbaceous standing crop was unchanged, but perennial grass standing crop declined by over $50 \%$ when the last 3 years of study were compared with the first 3 years of study. Broom snakeweed (Gutierrezia sarothrae Pursh), a poisonous half shrub, increased in standing crop and cover during the study. Basal cover of total perennial grasses declined less under light than conservative stocking during the study period. However, climatic conditions exerted the overriding influence on vegetation standing crop and basal cover. Our study indicates that light stocking in the Chihuahuan Desert does not increase perennial grass production compared to conservative grazing but it could have a small benefit in maintaining perennial grass cover during drought. We believe our findings have broad application in the Chihauhuan Desert, but caution they might not apply well to other arid rangeland types.
\end{abstract}

\section{Resumen}

Se evaluaron los cambios de vegetación por un periodo de 11 años (1995-2005) en dos poteros del Desierto Chihuahuense de la región sur-central de New Mexico con carga animal ligera y dos con una carga animal conservadora. Los tratamientos de apacentamiento fueron aplicados a los potreros por un periodo de cinco años de 1997 al 2001. Los poteros no se apacentaron en los periodos de 1995-1996 y 2002-2005 debido a la sequía. Durante el periodo de apacentamiento 1997-2001, la utilización de las principales especies forrajeras promedio $29 \%$ y $40 \%$ en los pastizales con cargas ligera y conservadora respectivamente. La intensidad de apacentamiento fue consistentemente mayor en los potreros con carga conservadora que en los de carga ligera. Durante nuestro estudio, solo en un año ocurrió apacentamiento fuerte en los potreros con carga conservadora. Entre cargas animal no hubo diferencias en la biomasa de otoño y la cobertura basal de las especies o categorías de especies (zacates, hierbas, y arbustos). La biomasa de la vegetación total y de los zacates perennes presentó grandes fluctuaciones entre años, debido a la variabilidad de la precipitación. Bajo ambos tratamientos, la biomasa total herbácea no fue modificada, pero la biomasa de los zacates perennes disminuyó en $50 \%$ cuando se compararon los tres últimos años con los tres primeros del estudio. La biomasa y cobertura del "Broom snakeweed" (Gutierrezia sarothrae Pursh), un arbusto tóxico, aumentaron durante el estudio. Así mismo, durante el estudio, la cobertura basal total de los zacates perennes disminuyó menos con la carga ligera. Sin embargo, las condiciones climáticas ejercieron una influencia abrumadora sobre la biomasa y la cobertura basal de la vegetación. Nuestro estudio indica que, en el Desierto Chihuahuense, la carga animal ligera en comparación con la carga animal conservadora no aumenta la producción de los zacates perennes, pero puede tener un pequeño beneficio al mantener la cobertura de los zacates perennes durante la sequía. Creemos que nuestros hallazgos tienen una amplia aplicación en el Desierto Chihuahuense, pero cuidado, porque ellos pueden no aplicar bien en otros tipos de pastizales áridos.

Key Words: arid lands, forage, stocking rate, drought, ecological condition, cattle

\section{INTRODUCTION}

This research was supported by the New Mexico Agriculture Experimental Station, New Mexico State University, Las Cruces, NM 88003 and was part of project 0172944.

Correspondence: Jerry Holechek, Dept of Animal and Range Sciences, 2980 South Espina Street, MSC 31, New Mexico State University, Las Cruces, NM 88003. Email: holechek@nmsu.edu

Manuscript received 27 April 2006; manuscript accepted 9 November 2006.
Knowledge of the relationships between stocking rate and plant production is fundamental to sustainable management of rangelands. Selection of appropriate stocking rate is the most important of all grazing management decisions from the standpoint of vegetation, livestock, wildlife, and economic returns (Heady and Child 1994; Hart and Ashby 
1998; Tainton 1999; Gillen and Sims 2004; Holechek et al. 2004).

A descriptive study by Holechek (1992) and an experimental study by Winder et al. (2000) have indicated that conservative stocking $(31 \%-40 \%$ use of forage) in the Chihuahuan Desert will provide higher financial returns from cow-calf operations compared to moderate stocking $(41 \%-50 \%$ use). Generally, the long-term benefits of conservative stocking are now fairly well-established based on reviews by Vallentine (2000) and Holechek et al. (2004). A 5 -year study by Hawkes (2004) on Chihuahuan Desert rangeland indicated that net returns per hectare from the cow-calf production were higher under conservative than light (less than $31 \%$ use) stocking. However, over twice as many cows were traded with the conservativestocking strategy as with the light-stocking strategy. In recent years many ranchers on Chihuahuan Desert rangelands in the southwestern United States have become interested in light grazing as a hedge against ongoing drought conditions and cattle price fluctuations. Light grazing allows palatable forage species to maximize their herbage-producing ability (Holechek et al. 2004). It can reduce risk of damaging the range and drastic destocking during drought periods when cattle prices are often unfavorable. Research by Valentine (1970) on Chihuahuan Desert rangeland in New Mexico indicated light compared to conservative stocking can accelerate recovery of range vegetation from drought compared to conservative stocking. The objectives of our study were to compare the effects of 5 years of light- and conservative-cattle stocking levels on forage production and vegetation cover on Chihuahuan Desert Rangeland Research Center (CDRRC) in south central New Mexico. We hypothesized that light and conservative stocking would have the same effects on trend in perennial grass standing crop and basal cover during our period of study. We attempted to stock conservative grazed pastures at a $33 \%$ higher rate than those light grazed.

\section{MATERIALS AND METHODS}

\section{Study Area Description}

The study area was located on the New Mexico State University (NMSU) Chihuahuan Desert Rangeland Research Center (CDRRC) (lat $32^{\circ} 32^{\prime} 30^{\prime \prime} \mathrm{N}$, long $106^{\circ} 52^{\prime} 30^{\prime \prime} \mathrm{W}$ ) operated by New Mexico State University, $37 \mathrm{~km}$ north of Las Cruces, NM, in Dona Ana County. This flat to gently rolling area is in the southern portion of the Jornada del Muerto Plains between the San Andres Mountains to the east and the Rio Grande Valley to the west. The CDRRC covers an area of 25546 ha and elevation varies from $1330 \mathrm{~m}$ at the Rio Grande River to $1945 \mathrm{~m}$ at the peak of Summerford Mountain. Soils of the CDRRC are fine loamy, mixed, thermic, typic haplargids of the Simona-Cruces association (Tembo 1990) underlain by calcium carbonate hard pan (caliche) at depths varying from a few centimeters to $1 \mathrm{~m}$ or more (Valentine 1970). In areas where the ground cover is sparse, sand dunes form around the invading mesquite (Prosopis glandulosa Torr.) plants (Wood 1969).

\section{Climate}

The climate on CDRRC is arid, with an average of 200 days in the frost-free period. Temperatures are high, with a mean maximum of $36^{\circ} \mathrm{C}$ during June, and a mean maximum of $13^{\circ} \mathrm{C}$ during January (Pieper and Herbel 1982). Temperature differences are substantial between day and night. Strong winds in the spring cause severe erosion and water stress plants (Pieper and Herbel 1982).

Annual precipitation is bimodal. Summer precipitation (July-September) is from localized convectional storms of high intensity but low frequency. Winter precipitation (December-February) is relatively gentle and evenly distributed. Mean annual precipitation is $234 \mathrm{~mm}$, with $52 \%$ of the annual rainfall occurring during summer.

\section{Vegetation}

Primary grass species on our study area include black grama (Bouteloua eriopoda Torr.), dropseeds (Sporobolus sp.), threeawns (Aristida sp.), bush muhly (Mublenbergia porteri Kunth.), fluffgrass (Erioneuron pulchellum Tateoka), and tobosa (Hilaria mutica Buckley). The most commonly encountered shrub species is honey mesquite (Prosopis glandulosa Torr.), which dominates the overstory and has been increasing over the past 100 years (Pieper and Herbel 1982). Other shrubs include broom snakeweed (Gutierrezia sarothrae Pursh), soaptree yucca (Yucca elata Engelm.), and creosotebush (Larrea tridentata [Pursh] Nutt.). Leatherweed croton (Croton pottsii Lam.), the primary forb, is an important food for livestock and pronghorn antelope (Antelocapra americana).

\section{Historical Background}

Four pastures with similar soils (sandy loams), topography (flat), and size were delineated and fenced in 1991 (Winder et al. 2000; Joseph et al. 2003). These include pasture 1 (1 267 ha), pasture 2 (932 ha), pasture 3 (1 $219 \mathrm{ha}$ ), and pasture 4 (974 ha). These pastures are adjacent to each other and are surrounded by rangeland in midseral condition. The spatial ordering of the pastures from west to east was $1,2,3$, and 4 . These pastures have flat terrain and similar spacing of watering points. The only permanent water sources are wells and pipelines provided for livestock use. During 1992, 1993, and 1994, these pastures were used to study the effects of range condition and grazing intensity on cattle production (Winder et al. 2000) and wildlife populations (Nelson et al. 1997; Joseph et al. 2003).

Pastures 1 and 4 were stocked with cattle at a conservative rate $(30 \%-35 \%$ use), and pastures 2 and 3 were stocked at moderate rate $(40 \%-45 \%)$ from June of 1992 until late July of 1994. They were destocked in late July of 1994 due to onset of drought (Nelson 1996). Grazing was reinitiated in January 1997.

In the autumn of 1995 and 1996 comprehensive range vegetation inventories of pastures $1,2,3$, and 4 were made by a certified range consultant (Dr Dee Galt) and a NMSU range scientist (Dr Jerry Holechek), to establish baseline vegetation data for future range research. This inventory characterized range sites and ecological condition through quantification of total standing crop and basal plant cover in autumn of 1995 and 1996. It provided a basis for future evaluation of trends in vegetation productivity and ground cover in response to grazing treatments. 
Table 1. Average growing season and annual precipitation on the Chihuahuan Desert Rangeland Research Center in south central New Mexico from 1995 to 2005.

\begin{tabular}{|c|c|c|c|c|c|c|c|c|c|c|c|c|c|c|}
\hline Year & Jan & Feb & Mar & April & May & June & July & Aug & Sept & Oct & Nov & Dec & $\begin{array}{c}\text { Growing season } \\
\text { precipitation1 }(\mathrm{mm})\end{array}$ & $\begin{array}{c}\text { Annual } \\
\text { precipitation (mm) }\end{array}$ \\
\hline 1995 & 26 & 14 & 1 & 0 & 0 & 18 & 21 & 41 & 42 & 0 & 2 & 6 & 104 & 170 \\
\hline 1996 & 7 & 1 & 0 & 15 & 0 & 25 & 57 & 21 & 52 & 18 & 5 & 0 & 130 & 200 \\
\hline 1997 & 16 & 14 & 18 & 3 & 11 & 42 & 57 & 68 & 26 & 10 & 12 & 36 & 151 & 312 \\
\hline 1998 & 1 & 8 & 11 & 1 & 0 & 3 & 60 & 35 & 13 & 59 & 15 & 7 & 108 & 214 \\
\hline 1999 & 10 & 0 & 7 & 0 & 11 & 62 & 39 & 65 & 65 & 20 & 0 & 11 & 169 & 290 \\
\hline 2000 & 0 & 0 & 17 & 2 & 0 & 121 & 15 & 16 & 1 & 53 & 38 & 3 & 32 & 265 \\
\hline 2001 & 10 & 11 & 3 & 1 & 10 & 6 & 22 & 22 & 68 & 0 & 4 & 6 & 112 & 162 \\
\hline 2002 & 4 & 21 & 0 & 0 & 5 & 0 & 28 & 15 & 17 & 25 & 7 & 34 & 60 & 157 \\
\hline 2003 & 0 & 41 & 3 & 0 & 0 & 24 & 4 & 18 & 5 & 14 & 17 & 1 & 27 & 127 \\
\hline 2004 & 9 & 0 & 19 & 62 & 1 & 31 & 21 & 47 & 58 & 29 & 43 & 16 & 126 & 336 \\
\hline 2005 & 31 & 48 & 12 & 11 & 19 & 0 & 7 & 23 & 26 & 21 & 0 & 0 & 56 & 198 \\
\hline Study average & & & & & & & & & & & & & 98 & 221 \\
\hline 1995-1997 average & & & & & & & & & & & & & 128 & 227 \\
\hline 2003-2005 average & & & & & & & & & & & & & 70 & 220 \\
\hline Long-term average, 1931-2005 & & & & & & & & & & & & & & 234 \\
\hline
\end{tabular}

${ }^{1}$ Growing season is July through September.

\section{Description of Sampling Techniques}

Vegetation sampling. Data collection for our study was carried out in autumn of every year between October and November in the 1995-2005 period. It involved vegetation measurement of total standing crop, forage production, and plant basal cover. Measurements were taken on 10 permanent, evenly spaced key areas in each pasture (40 key areas total). A transect-point intercept method was used to determine ground cover and plant composition at each key area (Bonham 1989; Elzinga et al. 1998). At each key area, a 61-m line transect was located by driving a rebar stake at each end of the line and one in the center. Plant basal cover was measured using a pin flag along a tape as close to the ground as possible and stretched between 2 permanent rebar stakes. The pin flag was dropped vertically and without guiding it from the same height each time. Readings were taken from left to right of the zero mark at $0.61 \mathrm{~m}$ intervals, giving a total of 100 measurements per transect. Data were recorded by plant species, litter, rock, gravel, and bare soil.

For herbaceous biomass production, the direct method of harvesting or clipping as described by Bonham (1989) was used in this study. Herbage production was measured by offsetting the $61-\mathrm{m}$ line by $3 \mathrm{~m}$ and placing $10,0.5 \mathrm{~m}^{2}$ quadrats parallel to the first line at $6.10 \mathrm{~m}$ intervals. Because of the destructive nature of clipping, plots were shifted $1 \mathrm{~m}$ forward each year to avoid previously clipped areas. Vegetation was clipped at ground level and hand separated by species in the field. Only current year's growth was measured. Plant samples from clipped plots were oven dried 24 hours at $55^{\circ} \mathrm{C}$ for dry weight analysis.

Rangeland ecological condition scores were calculated from current USDA Natural Resources Conservation Service site guides for New Mexico using the Dyksterhuis (1949) procedure. We used range site no. D42-15-NTx, shallow sandy site (SD-2) and site no. D42-12-NTx, sandy range site (SD-2).
Relative percent composition of autumn current year standing herbage was used to calculate rangeland ecological condition scores for each year of the study (1995-2005).

To study long-term vegetation trends from 1995 to 2005, data were pooled across the first 3 years (1995-1997) and the last 3 years (2003-2005) of the study. In an analysis of grazing experiments, Holechek et al. (1999) found data pooled across the first and last 3 years of study gave the most meaningful comparisons of long-term vegetation changes. This particularly applies in areas where ecological condition and forage production might not be equivalent across grazing treatments at study initiation and precipitation varies greatly among years.

\section{Stocking Rate and Grazing Intensity}

From January 1997 through late autumn 2001 we attempted to graze pastures 1 and 3 at a light $(30 \%$ use) intensity and pastures 2 and 4 at a conservative ( $40 \%$ use) intensity. Actual stocking levels assigned to light- and conservative-grazed treatments were, respectively, 124 and 63 ha $\cdot$ animal unit year $(\mathrm{AUY})^{-1}$ in 1997,67 and $39 \mathrm{ha} \cdot \mathrm{AUY}^{-1}$ in 1998, 84 and $16 \mathrm{ha} \cdot \mathrm{AUY}^{-1}$ in 1999, 112 and $24 \mathrm{ha} \cdot \mathrm{AUY}^{-1}$ in 2000, and 141 and $57 \mathrm{ha} \cdot \mathrm{AUY}^{-1}$ in 2001. All cattle were removed from the pastures in late November 2001 due to lack of forage from drought. Livestock grazing was discontinued on our study pastures in the 2002 through 2005 period due to drought and to allow better quantification of the 2 grazing treatments we applied in the 1997-2001 period. Detailed information on livestock management on the study pastures is provided by Thomas et al. (2000) and Hawkes (2004). The pastures were grazed by Brangus cows with each pasture assigned a single sire-mated herd.

Grazing intensity on the 4 pastures was evaluated in early June of 1997, 1998, 1999, 2000, and 2001 using procedures of Holechek and Galt (2000). Percent use of forage, residual vegetation and stubble heights of key species were evaluated on 


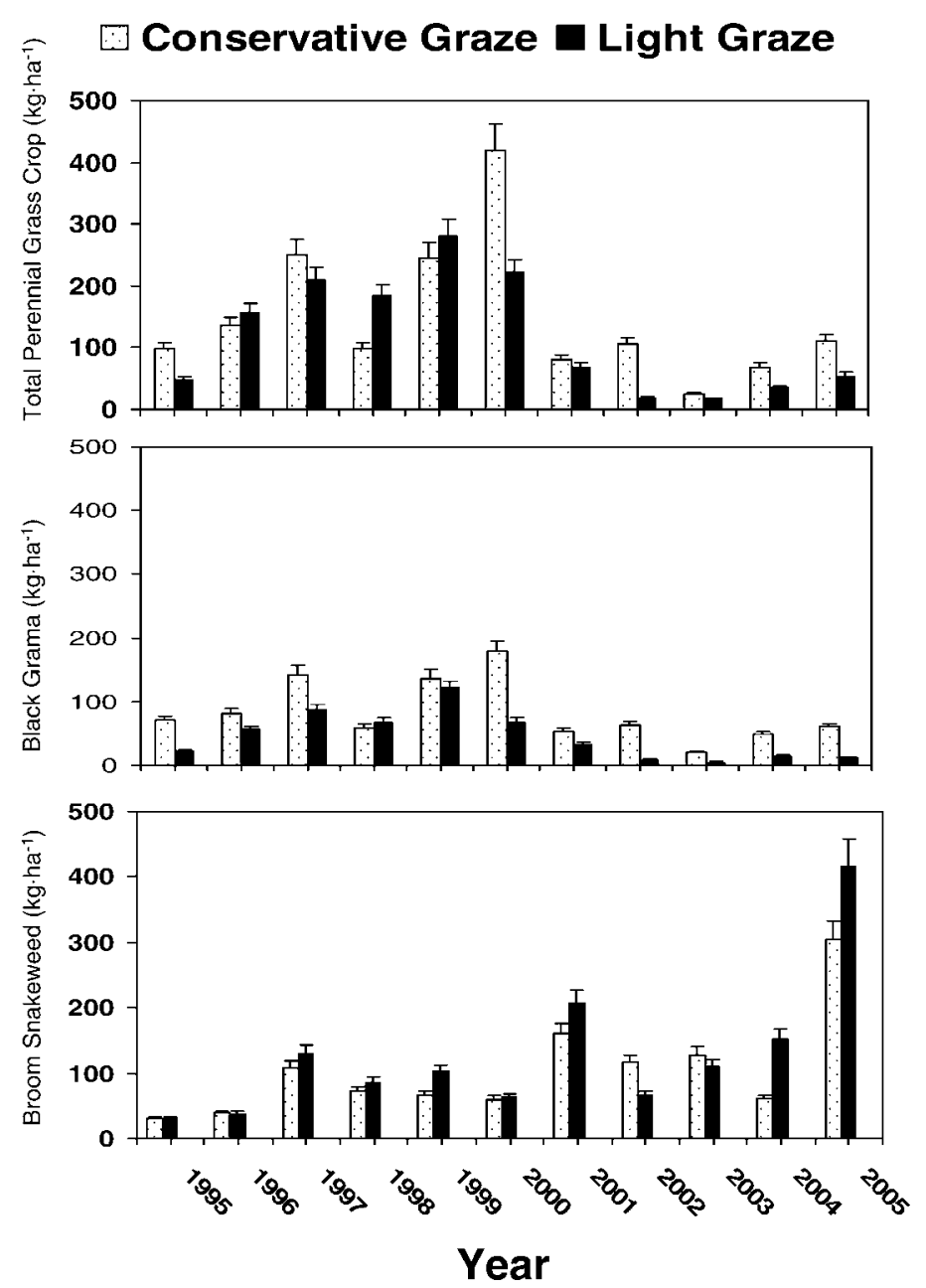

Figure 1. Autumn total perennial grasses, black grama, and broom snakeweed standing crop under light- and conservative-grazing treatments over an 11-year period on the Chihuahuan Desert Rangeland Research Center.

4 of the key areas evenly spaced within each pasture. Two 100-m transects were established each year for these evaluations. Percent use and residual vegetation were determined by clipping $10,0.5-\mathrm{m}^{2}$ quadrats at $10-\mathrm{m}$ intervals on $100-\mathrm{m}$ transect for a total of 20 per key area. Twenty-five black grama plants were measured at 4-m increments for stubble height along each of the two 100-m transects at each key area on the opposite side used for current year growth evaluation. The nearest forward black grama plant was measured at each interval. A total of 50 plants was measured at each key area.

\section{Data Analysis}

Effects of grazing treatment, year, and interactions for standing crop of total vegetation, total grasses, black grama, and broom snakeweed were analyzed using a repeated measures analysis and SAS PROC MIXED software (SAS Institute, Inc., 1999). Pastures were used as replications for comparing grazing treatments. This same analysis was used to evaluate trend in standing crop and basal cover. The first 3 years (1995-1997) and last 3 years (2003-2005) of the study were pooled together for trend analysis. The 2 grazing treatments (light and conservative) and the 2 time periods (1995-1997 and 20032005) were factors and pastures (2 per stocking treatment) were used as replicates. Each species or species group was analyzed separately.

\section{RESULTS AND DISCUSSION}

\section{Perennial Grass Standing Crop and Precipitation}

Average annual precipitation during the 1995-2005 study period was $94 \%$ of the long-term average (Table 1). Drought ( $75 \%$ or less of average annual precipitation) occurred in 4 years $(1995,2001,2002,2003)$. Total precipitation for the first and last 3 years of study were similar (227 vs. $220 \mathrm{~mm}$ ). However, growing season precipitation was $83 \%$ higher in the first 3 years compared to last 3 years of study.

Autumn perennial grass and black grama standing crop did not differ $(P>0.1)$ between light- and conservative-grazed treatments, but year effect was significant (Fig. 1). Grazing treatment $\times$ year interactions were not significant $(P>0.1)$. Therefore, vegetation did not respond inconsistently to light and conservative stocking over time. Vegetation changes in response to climatic fluctuations from year to year are to be expected based on various grazing studies reviewed by Vallentine (2000) and Holechek et al. (2004). Our research is consistent with Herbel and Gibbens (1996), Holechek et al. (2003), and Khumalo and Holechek (2005) in showing Chihuahuan Desert rangelands are characterized by extreme fluctuations in annual forage production.

Years 1997, 1999, and 2000 had the highest standing crop for black grama, total grasses, and total vegetation. These were years in which precipitation was above the long-term annual average, and, except for year 2000, they also had aboveaverage growing season precipitation. It is noteworthy that although 2004 had the highest annual precipitation $(336 \mathrm{~mm})$ during the 11 years of our study, it is among the lowest in terms of autumn standing crop. Most of the growing season precipitation in 2004 occurred in September (Table 1) when temperatures were cooling and conditions were less than optimal for perennial grass growth. Therefore it probably contributed little to perennial grass growth. An additional explanation is that storms during the summer of 2004 occurred as infrequent, low intensity events. Navarro et al. (2002) observed that precipitation from infrequent storms through July and August involving less than $7.6 \mathrm{~mm}$ of rainfall was quickly lost to evaporation. They noted that generally about $25.4 \mathrm{~mm}$ of rainfall concentrated within a 1 week period is needed to initiate growth of desert grasses such as black grama and tobosa.

The year 2005 was among the lowest standing-crop years for black grama but was the highest standing-crop year for broom snakeweed, total forbs, and total vegetation (Fig. 1). Broom snakeweed is a short-lived perennial, cyclic, half shrub in the Asteraceae family. It contains a rich mixture of alkaloids, flavonoids, saponins, terpenes, and other compounds that are toxic to rangeland livestock. It can cause abortion in livestock and has severely depressed productivity of perennial grasses on New Mexico rangelands (McDaniel et al. 1993). Populations of broom snakeweed are closely related to climatic conditions (Pieper and McDaniel 1989). Above normal autumn through 
Table 2. Average autumn herbaceous standing crop $\left(\mathrm{kg} \cdot \mathrm{ha}^{-1}\right)$, standing crop relative herbaceous composition (\%) and rangeland ecological condition score (\%) on light- (LG) and conservative-stocked (CG) rangelands for 1995-1997 and 2003-2005 periods on the Chihuahuan Desert Rangeland Research Center. Means within the same row and response variable followed by different lowercase letters differ at the $P<0.1$ level.

\begin{tabular}{|c|c|c|c|c|c|c|c|}
\hline \multirow{3}{*}{$\begin{array}{l}\text { Species/group and } \\
\text { rangeland condition }\end{array}$} & \multirow{3}{*}{$\begin{array}{l}\text { Graze } \\
\text { level1 }\end{array}$} & \multicolumn{3}{|c|}{ Autumn standing crop2 } & \multicolumn{3}{|c|}{ Standing crop relative composition } \\
\hline & & 1995-1997 & 2003-2005 & \multirow[b]{2}{*}{ SE3 } & $1995-1997$ & 2003-2005 & \multirow[b]{2}{*}{ SE3 } \\
\hline & & \multicolumn{2}{|c|}{$\left(\mathrm{kg} \cdot \mathrm{ha}^{-1}\right)$} & & \multicolumn{2}{|c|}{$(\%)$} & \\
\hline \multirow[t]{2}{*}{ Aristida spp. } & LG & 18 & 4 & 12.0 & 5.5 & 1.0 & 3.7 \\
\hline & $C G$ & 26 & 17 & 12.0 & 7.0 & 4.0 & 3.7 \\
\hline \multirow[t]{2}{*}{ Bouteloua eriopoda } & LG & 55 & 10 & 12.0 & 17.5 & 3.5 & 4.2 \\
\hline & CG & 99 & 43 & 12.0 & 32.5 & 13.5 & 4.2 \\
\hline \multirow[t]{2}{*}{ Sporobolus spp. } & LG & $46 a$ & $11 b$ & 8.8 & $13.5 a$ & $1.5 b$ & 1.0 \\
\hline & CG & 21 & 8 & 8.8 & $6.5 a$ & $2.5 b$ & 1.0 \\
\hline \multirow[t]{2}{*}{ Total grasses } & LG & $139 a$ & $35 b$ & 4.6 & $44.0 \mathrm{a}$ & $8.5 b$ & 0.7 \\
\hline & CG & $162 \mathrm{a}$ & $68 b$ & 4.6 & $51.0 \mathrm{a}$ & $20.5 b$ & 0.7 \\
\hline \multirow[t]{2}{*}{ Croton potsii } & LG & $31 a$ & $15 b$ & 1.8 & $11.0 \mathrm{a}$ & $3.5 b$ & 0.4 \\
\hline & CG & $33 a$ & $25 b$ & 1.8 & 10.5 & 8.5 & 0.4 \\
\hline \multirow[t]{2}{*}{ Total forbs } & $L G$ & 82 & 113 & 12.4 & 32.0 & 23.0 & 1.4 \\
\hline & $C G$ & 82 & 100 & 12.4 & 28.0 & 30.0 & 1.4 \\
\hline \multirow[t]{2}{*}{ Gutierrezia sarothrae } & LG & $66 \mathrm{~b}$ & $223 a$ & 45.9 & $19.5 b$ & $56.0 \mathrm{a}$ & 5.3 \\
\hline & CG & $59 b$ & $164 a$ & 45.9 & $18.0 \mathrm{~b}$ & $48.0 \mathrm{a}$ & 5.3 \\
\hline \multirow[t]{2}{*}{ Total vegetation } & $L G$ & 301 & 363 & 61.9 & 100 & 100 & - \\
\hline & CG & 312 & 326 & 61.9 & 100 & 100 & - \\
\hline \multirow[t]{2}{*}{ Rangeland condition score } & LG & & & & $64 a$ & $27 b$ & 6.2 \\
\hline & CG & & & & $69 a$ & $41 b$ & 6.2 \\
\hline
\end{tabular}

${ }^{1}$ Graze levels were light grazing (LG), $29 \%$ use, and conservative grazing (CG), 40\% use of current year forage production.

2Data were pooled across the first 3 years and the last 3 years of study for trend comparisons as suggested by Holechek et al. (1999).

${ }^{3}$ Standard errors of differences between treatments.

spring precipitation favors broom snakeweed establishment. The wet autumn through spring and relatively dry summer in 2005 explain the high production of broom snakeweed and low production of perennial grasses.

\section{Grazing Intensity}

Grazing use across all forage grasses averaged $28.8 \pm 4.3 \%$ in light-stocked pastures and $39.8 \pm 4.4 \%$ in conservativestocked pastures during the 1997 to 2001 study period. Specifically, in June 1997, 1998, 1999, 2000, and 2001, grazing use was $14 \%$ and $21 \%, 36 \%$ and $46 \%, 39 \%$ and $56 \%, 25 \%$ and $37 \%$, and $30 \%$ and $39 \%$, respectively. Grazing use was consistently higher on conservative- than light-stocked pastures.

Stubble heights of key forage grasses better reflect grazing severity and are a more precise indicator of grazing intensity than percent use of forage (Valentine 1970; Holechek and Galt 2000; Holechek et al. 2003). Black grama stubble heights in June grazing intensity surveys on light-stocked pastures averaged $12.84 \pm 1.21 \mathrm{~cm}$ compared to $10.02 \pm 0.68 \mathrm{~cm}$ on conservative-stocked pastures. Valentine (1970) recommended that a minimum stubble height of $7.6 \mathrm{~cm}$ be maintained on black grama to avoid decline in productivity. During the 19972001 study period stubble heights of black grama on all pastures averaged above $7.6 \mathrm{~cm}$ with 1 exception. However in 1999 black grama stubble heights averaged $9.75 \pm 1.82 \mathrm{~cm}$ on light-stocked pastures compared to $6.89 \pm 0.87 \mathrm{~cm}$ on conservative-stocked pastures. It appears that 1 year of heavy grazing $(51 \%-60 \%$ use) does not harm black grama if followed by conservative grazing. In 1999 black grama production on light- and conservative-stocked pastures was similar, but in 2000 black grama production on conservative-stocked pastures was over twice that on light-stocked pastures (Fig. 1).

\section{Trend in Standing Crop and Basal Cover}

No differences $(P>0.1)$ occurred in autumn herbaceous standing crop components between light and conservative stocking for either the 1995-1997 or 2003-2005 periods (Table 2). All interactions between grazing treatments and periods were nonsignificant $(P>0.1)$. However, some plant species and plant categories had standing crop differences $(P<0.1)$ between periods. Total grasses standing crop declined $(P<0.1)$ from 1995-1997 to 2003-2005, but broom snakeweed increased. This resulted in lower $(P<0.1)$ rangeland ecological condition across both grazing treatments in the 2003-2005 period than in the 1995-1997 period. We attribute this downward trend to less growing season precipitation during the latter period of our study and to the relatively wet winterspring and dry summer in 2005 that favored broom snakeweed.

Autumn basal cover of plant species and groups was generally consistent with autumn standing crop data (Table $3)$. There were no grazing treatment or grazing treatment $x$ year interactions for any vegetation component $(P>0.1)$. However, total perennial grass and black grama basal cover declined $(P<0.1)$ on the conservative-stocked treatment while broom snakeweed increased on both treatments from 1995- 
Table 3. Average autumn vegetation basal cover (\%) and relative basal cover vegetation composition (\%) on light- (LG) and conservative-stocked (CG) rangelands for 1995-1997 and 2003-2005 periods on the Chihuahuan Desert Rangeland Research Center. Means within the same row and response variable followed by different lowercase letters differ at the $P<0.1$ level.

\begin{tabular}{|c|c|c|c|c|c|c|c|}
\hline \multirow[b]{3}{*}{ Species/group } & \multirow{3}{*}{$\begin{array}{l}\text { Graze } \\
\text { level }^{1}\end{array}$} & \multicolumn{3}{|c|}{ Vegetation basal cover ${ }^{2}$} & \multicolumn{3}{|c|}{ Relative basal vegetation composition } \\
\hline & & $1995-1997$ & 2003-2005 & \multirow[b]{2}{*}{ SE3 } & 1995-1997 & 2003-2005 & \multirow[b]{2}{*}{$\mathrm{SE}^{3}$} \\
\hline & & \multicolumn{2}{|c|}{$(\%)$} & & \multicolumn{2}{|c|}{$(\%)$} & \\
\hline \multirow[t]{2}{*}{ Aristida spp. } & $L G$ & 0.2 & 0.05 & 0.3 & 10.0 & 1.0 & 8.5 \\
\hline & $C G$ & 0.45 & 0.15 & 0.3 & 14.0 & 4.0 & 8.5 \\
\hline \multirow[t]{2}{*}{ Bouteloua eriopoda } & $\mathrm{LG}$ & 0.7 & 0.3 & 0.2 & 9.5 & 7.0 & 2.2 \\
\hline & CG & $1.4 \mathrm{a}$ & $0.8 \mathrm{~b}$ & 0.2 & $27.0 \mathrm{a}$ & $17.0 \mathrm{~b}$ & 2.2 \\
\hline \multirow[t]{2}{*}{ Sporobolus spp. } & $\mathrm{LG}$ & 0.3 & 0.2 & 0.3 & 10.0 & 5.5 & 6.0 \\
\hline & $C G$ & 0.4 & 0.05 & 0.3 & 8.0 & 0.5 & 6.0 \\
\hline \multirow[t]{2}{*}{ Total grasses } & LG & 1.5 & 1.2 & 0.4 & $40.5 \mathrm{a}$ & $27.5 b$ & 2.0 \\
\hline & $C G$ & $2.6 \mathrm{a}$ & $1.0 \mathrm{~b}$ & 0.4 & $58.0 \mathrm{a}$ & $23.0 \mathrm{~b}$ & 2.0 \\
\hline \multirow[t]{2}{*}{ Croton potsii } & $L G$ & 0.3 & 0.2 & 0.1 & $12.5 \mathrm{a}$ & $4.5 b$ & 0.4 \\
\hline & $C G$ & 0.3 & 0.2 & 0.1 & $8.0 \mathrm{a}$ & $4.5 b$ & 0.4 \\
\hline \multirow[t]{2}{*}{ Total forbs } & $L G$ & 0.6 & 1.0 & 0.4 & 29.5 & 20.5 & 8.7 \\
\hline & $C G$ & 0.7 & 1.4 & 0.4 & 24.5 & 28.0 & 8.7 \\
\hline \multirow[t]{2}{*}{ Gutierrezia sarothrae } & $L G$ & $0.3 b$ & $1.9 \mathrm{a}$ & 0.2 & $15.5 b$ & $41.0 \mathrm{a}$ & 4.5 \\
\hline & CG & $0.3 b$ & $1.6 \mathrm{a}$ & 0.2 & $5.5 b$ & $36.0 \mathrm{a}$ & 4.5 \\
\hline \multirow[t]{2}{*}{ Total vegetation } & $L G$ & 4.7 & 7.2 & 1.3 & 100 & 100 & \\
\hline & CG & 6.9 & 6.8 & 1.3 & 100 & 100 & \\
\hline
\end{tabular}

${ }^{1}$ Graze levels were light grazing (LG), $29 \%$ use, and conservative grazing (CG), $40 \%$ use of current year forage production.

${ }^{2}$ Data were pooled across the first 3 years and the last 3 years of study for trend comparisons as suggested by Holechek et al. (1999).

${ }^{3}$ Standard errors of differences between treatments.

1997 to 2003-2005. The lack of decline in total perennial grass cover under light compared to conservative stocking indicates light grazing might be advantageous to perennial grass persistence during drought. Holechek et al. (2003) found perennial grass cover was better maintained during drought on lightstocked compared to moderate-stocked Chihuahuan Desert rangelands. We allow that basal cover of perennial grasses might have been better maintained under light than conservative stocking because of higher starting levels on the conservative-stocked pastures. It is also possible this difference was due to sampling variability rather than grazing treatment.

Dropseeds, the second most important grasses on our study pastures, showed no reduction $(P>0.1)$ in cover under either light or conservative stocking but dropseed standing crop was reduced from 1995-1997 to 2003-2005 under light grazing. We cannot satisfactorily explain this inconsistency other than that it is probably due to sampling variability rather than grazing treatment.

\section{MANAGEMENT IMPLICATIONS}

Results from our study in the Chihuahuan Desert indicate light stocking over a 5-year period had no benefit over conservative stocking in terms of increasing perennial grass productivity. We found limited evidence that basal cover of perennial grasses was better maintained under light than conservative stocking when the last 3 years were compared with the first 3 years of study. However, this might have been due to sampling variability. Over a 10-year period, Valentine (1970) found recovery of black grama after drought was more rapid under light than conservative grazing. Black grama, the key forage grass on our study area, was not heavily grazed on either of the light-stocked pastures in any year of study. During 1999 the 2 conservativestocked pastures were heavily grazed but during the other 4 years of the study these pastures were grazed at light to moderate levels. Perennial grass production was similar on light- and conservative-stocked pastures in 1999 but higher on conservative-stocked pastures in 2000. Therefore we conclude that 1 year of heavy grazing does not reduce black grama stand productivity if followed by conservative grazing the next year. Our research supports the recommendation by Valentine (1970) that a minimum stubble height of $7.6 \mathrm{~cm}$ be maintained on black grama stands. Our study indicates light stocking in the Chihuahuan Desert better maintains cover of perennial grasses during drought than heavier stocking levels. Other studies have shown light stocking is advantageous over heavier stocking levels in facilitating recovery of black grama stands after drought (Valentine 1970) and in avoiding herd liquidations during short term drought (Thomas et al. 2007). Therefore, we consider light stocking in the Chihuahuan Desert a practical management tool for drought years. Studies are lacking from other arid rangeland types that compare the effects of light and conservative stocking on vegetation responses. We consider our results to apply well to Chihuahuan Desert rangelands but caution they might not be applicable to other arid rangeland types.

\section{LITERATURE CITED}

Bonham, C. D. 1989. Measurements for terrestrial vegetation. New York, NY: John Wiley and Sons, $338 \mathrm{p}$.

Dyksterhuis, E. J. 1949. Condition and management of rangelands based on quantitative ecology. Journal of Range Management 2:104-115.

Elzinga, C. L., D. W. Salzer, and J. W. Willoughby. 1998. Measuring and monitoring 
plant Populations. BLM Technical reference 1730-1. USDI, Denver, C0: BLM. 54 p.

Gillen, R. L., AND P. L. Sims. 2004. Stocking rate, precipitation, and herbage production on sand sagebrush-grassland. Journal of Range Management $57: 148-152$.

HaRT, R. H., AND M. M. AshBy. 1998. Grazing intensities, vegetation, and heifer gains: 55 years on shortgrass. Journal of Range Management 51:392-398.

HAWKES, J. M. 2004. Light and conservative grazing effects on Chihuahuan Desert cow-calf production and financial returns [dissertation]. Las Cruces, NM: New Mexico State University. $49 \mathrm{p}$.

Heady, H. F., AND R. D. Child. 1994. Rangeland ecology and management. Boulder, CO: Westview Press. 519 p.

Herbel, C. H., and R. P. Gibbens. 1996. Post-drought vegetation dynamics on arid rangelands of New Mexico. Las Cruces, NM: New Mexico Agricultural Experiment Station. Bulletin 776. $102 \mathrm{p}$.

HoleCHEK, J. L. 1992. Financial benefits of range management practices in the Chihuahuan desert. Rangelands 14:237-240.

Holechek, J. L., and D. Galt. 2000. Grazing intensity guidelines. Rangelands 21: $11-14$.

Holechek, J., D. Galt, J. Joseph, J. Navarro, G. Khumalo, F. Molinar, and M. Thomas. 2003. Moderate and light grazing effects on Chihuahuan Desert rangelands. Journal of Range Management 56:133-139.

Holechek, J. L., R. D. Pieper, and C. H. Herbel. 2004. Range management: principles and practices. 5th ed. Upper Saddle River, NJ: Prentice-Hall. 607 p.

Holechek, J. L., M. Thomas, F. MolinaR, and D. Galt. 1999. Stocking desert rangelands: what we've learned. Rangelands 21:8-12.

Joseph, J., M. Collins, J. Holechek, R. Valdez, and R. Steiner. 2003. Conservative and moderate grazing effects on Chihuahuan Desert wildlife sightings. Western North American Naturalist 63:43-49.

Khumalo, G. Z., And J. L. Holechek. 2005. Relationships between Chihuahuan Desert perennial grass production and precipitation. Rangeland Ecology \& Management 58:239-246.

McDaniel, K. C., L. A. Torell, and J. W. Bain. 1993. Overstory-understory relationships for broom snakeweed-blue grama grasslands. Journal of Range Management 46:506-511.

Navarro, J. M., D. Galt, J. Holechek, J. McCormick, and F. Molinar. 2002. Long- term impact of livestock grazing on Chihuahuan Desert rangelands. Journal of Range Management 55:400-405.

Nelson, T. 1996. Wildlife numbers on good and fair condition Chihuahuan Desert rangelands [thesis]. Las Cruces, NM: New Mexico State University. 56 p.

Nelson, T., J. L. Holechek, R. Valdez, and M. Cardenas. 1997. Wildlife numbers on late and mid-seral Chihuahuan Desert rangelands. Journal of Range Management 50:593-599.

Pieper, R. D., And C. H. Herbel. 1982. Herbage dynamics and primary productivity of a desert grassland ecosystem. Las Cruces, NM: New Mexico Agricultural Experimental Station Bulletin 695. $43 \mathrm{p}$.

Pieper, R. D., and K. C. McDaniel. 1989. Ecology and management of broom snakeweed. Las Cruces, NM: New Mexico Agricultural Experimental Station. Bulletin 751. $12 \mathrm{p}$.

SAS Institute, Inc. 1999. SAS/STAT user's guide. Version 8. Cary, NC: SAS Institute Inc. 528 p.

Tainton, N. M. [ed.]. 1999. Veld Management in South Africa. Pietermaritzburg, South Africa: University of Natal Press. $264 \mathrm{p}$.

TemBo, A. 1990. Influence of watering points and range condition on vegetation of the Chihuahuan Desert [dissertation]. Las Cruces, NM: New Mexico State University. $127 \mathrm{p}$.

Thomas, M. G., C. C. Bailey, And J. L. Holechek. 2000. Conservative and moderate stocking effects on cow-herd performance in the Chihuahuan Desert. Proceedings Western Section, American Society of Animal Science 51:272276.

Thomas, M., J. Hawkes, G. Khumalo, and J. L. Holechek. 2007. Brangus cow-calf performance under two stocking levels on Chihuahuan Desert rangeland. Rangeland Ecology \& Management 60:110-114.

Valentine, K. A. 1970. Influence of grazing intensity on improvement of deteriorated black grama range. Las Cruces, NM: New Mexico Agricultural Experimental Station. Bulletin 553. $21 \mathrm{p}$.

Vallentine, J. F. 2000. Grazing Management. 2nd ed. New York, NY: Academic Press. 659 p.

Winder, J. A., C. C. Bailey, M. G. Thomas, and J. L. Holechek. 2000. Breed and stocking rate effects on Chihuahuan Desert cattle production. Journal of Range Management 53:32-39.

Wood, J. E. 1969. Rodent populations and their impact on desert rangelands. Las Cruces, NM: New Mexico Agricultural Experimental Station. Bulletin 555. 17 p. 